\title{
Reclassification of Lactobacillus amylophilus LMG 11400 and NRRL B-4435 as Lactobacillus amylotrophicus sp. nov.
}

\author{
Sabri M. Naser, ${ }^{1,2} \uparrow$ Marc Vancanneyt, ${ }^{2}$ Cindy Snauwaert, ${ }^{2}$ Gino Vrancken, ${ }^{3}$ \\ Bart Hoste, ${ }^{2}$ Luc De Vuyst ${ }^{3}$ and Jean Swings ${ }^{1,2}$
1,2 Laboratory of Microbiology ${ }^{1}$ and BCCM ${ }^{\mathrm{TM}} / \mathrm{LMG}$ Bacteria Collection ${ }^{2}$, Ghent University, K. L. Ledeganckstraat 35, B-9000 Ghent, Belgium
${ }^{3}$ Research Group of Industrial Microbiology and Food Biotechnology, Department of Applied Biological Sciences and Engineering, Vrije Universiteit Brussel (VUB), Pleinlaan 2, B-1050 Brussels, Belgium

Correspondence

Sabri M. Naser

Sabri.Naser@najah.edu

\begin{abstract}
The taxonomic position of six Lactobacillus amylophilus strains isolated from swine waste-corn fermentations was reinvestigated. All strains were included in a multilocus sequence analysis (MLSA) study for species identification of Lactobacillus using the genes encoding the phenylalanyl-tRNA synthase alpha subunit (pheS) and RNA polymerase alpha subunit (rpoA). Partial pheS and rpoA gene sequences showed that strains LMG 11400 and NRRL B-4435 represent a separate lineage that is distantly related to the type strain of $L$. amylophilus, $L M G 6900^{\top}$, and to three other strains of the species. The MLSA data showed that the two strains LMG 11400 and NRRL B-4435 constituted a distinct cluster, sharing $100 \%$ pheS and rpoA gene sequence similarity. The other reference strains clustered together with the type strain of $L$. amylophilus, LMG $6900^{\top}$, and were clearly differentiated from strains LMG 11400 and NRRL B-4435 (80 and $89 \%$ pheS and $r p o A$ gene sequence similarity, respectively). The 16S rRNA gene sequences of the latter two strains are $100 \%$ identical, with the nearest phylogenetic neighbour $L$. amylophilus LMG $6900^{\top}$ showing only $97 \cdot 2 \% 16 \mathrm{~S}$ rRNA gene sequence similarity. Further polyphasic taxonomic study based on whole-cell protein fingerprinting, DNA-DNA hybridization and biochemical features demonstrated that the two strains represent a single, novel Lactobacillus species, for which the name Lactobacillus amylotrophicus sp. nov. is proposed. The type strain is LMG $11400^{\top}$ (=NRRL B-4436 ${ }^{\top}=$ DSM $\left.20534^{\top}\right)$.
\end{abstract}

Lactobacillus amylophilus was first described by Nakamura \& Crowell (1979) based only on the phenotypic characterization of six strains (NRRL B-4435, LMG 11400, LMG 6900 ${ }^{\mathrm{T}}$, NRRL B-4438, NRRL B-4439 and NRRL B-4440) isolated from swine waste-corn fermentations. Few species of

tPresent address: Department of Biology and Biotechnology, Faculty of Sciences, An-Najah National University, Nablus, West Bank, Palestine.

The GenBank/EMBL/DDBJ accession numbers for the 16S rRNA gene sequences of LMG $11400^{\top}$ and NRRL B-4435 are AM236149 and AM236150, respectively. Other accession numbers reported in this paper are: partial pheS gene sequences for strains LMG $11400^{\top}$, NRRL B-4435, NRRL B-4438, NRRL B-4439 and NRRL B-4440, AM236139-AM236143; partial rpoA gene sequences for strains LMG $11400^{\top}$, NRRL B-4440, NRRL B-4435, NRRL B-4438 and NRRL B4439, AM236144-AM236148.

A distance-matrix tree based on $16 \mathrm{~S}$ rRNA gene sequences is available as supplementary material in IJSEM Online. lactobacilli are able to utilize amylose as a carbon and energy source. L. amylophilus is recognized as a starchutilizing species and displays extracellular amylolytic enzyme activity. L. amylophilus is a homofermentative lactic acid bacterium, which ferments starch to $\mathrm{L}(+)$-lactic acid (Nakamura \& Crowell, 1979). The strains of $L$. amylophilus also fermented fructose, galactose, glucose, mannose and maltose. Two strains (NRRL B-4435 and LMG 11400) fermented amygdalin, cellobiose and salicin weakly after 3 days or more (Nakamura \& Crowell, 1979). By further genotypic investigation, Nakamura (1982) showed high DNA-DNA reassociation values (90-98\%) among all these strains of the species. In an ongoing study of lactic acid bacteria diversity, these six strains of L. amylophilus were included in a multilocus sequence analysis (MLSA) study applied for the identification of Lactobacillus species. The results demonstrated that two strains, LMG 11400 and NRRL B-4435, occupied a distinct position. Further genomic and phenotypic research revealed that they represent a single novel species. 
The following culture collection strains were included in this study: L. amylophilus LMG $6900^{\mathrm{T}}$ ( = NRRL B-4437 ${ }^{\mathrm{T}}$ ), LMG 11400 (=NRRL B-4436), NRRL B-4435, NRRL B-4438, NRRL B-4439 and NRRL B-4440. All strains were cultivated and maintained on de Man, Rogosa and Sharpe (MRS) medium (Oxoid) and incubated at $37^{\circ} \mathrm{C}$ for $24 \mathrm{~h}$, unless otherwise indicated.

The use of housekeeping genes in bacterial taxonomy offers higher resolution than 16S rRNA gene sequence data at the species level as it integrates information from different molecular markers from throughout the bacterial chromosome (Stackebrandt et al., 2002; Zeigler, 2003). Sequencing of the housekeeping genes encoding the phenylalanyl-tRNA synthase alpha subunit ( $p h e S$ ) and RNA polymerase alpha subunit $(r p o A)$ provided robust identification of all enterococcal species (Naser et al., 2005a) and proved to be an efficient screening tool for the delineation of novel taxa (Naser et al., 2005b; Švec et al., 2005). In this study, we initially focused on partial pheS (304 bp) and rpoA (355 bp) gene sequences of L. amylophilus strains as a screening test to investigate their relatedness. Bacterial genomic DNA was extracted following the methodology described by Gevers et al. (2001). Amplification and sequencing reactions were performed as described by Naser et al. (2005a). Neighbourjoining trees of the investigated housekeeping genes showed that strains LMG 11400 and NRRL B-4435 constituted a distinct cluster, yielded $100 \%$ pheS and rpoA gene sequence similarity, and represented a separate lineage distantly related to L. amylophilus LMG $6900^{\mathrm{T}}$ (80 and $89 \%$ pheS and $r p o A$ gene sequence similarity, respectively) and to other lactobacilli (Fig. 1).

The phylogenetic position of strains LMG 11400 and NRRL B4435 was also studied by complete $16 \mathrm{~S}$ rRNA gene sequence analysis. Genomic DNA was prepared according to the protocol of Niemann et al. (1997). 16S rRNA gene amplification, purification and sequencing were performed as described by Vancanneyt et al. (2004) with the following modifications. PCR-amplified 16S rRNA genes were purified by using a NucleoFast 96 PCR Clean-up kit (MachereyNagel). Sequencing reactions were performed by using a BigDye Terminator cycle sequencing kit (Applied Biosystems) and purified by using a Montage $\mathrm{SEQ}_{96}$ sequencing reaction cleanup kit (Millipore). Sequencing was performed by using an ABI Prism 3100 Genetic Analyzer (Applied Biosystems). Sequence assembly was done by using the program Genebuilder (Applied Maths). The 16S rRNA gene sequences of strains LMG 11400 (1488 bp) and NRRL B-4435 (1525 bp) and gene sequences retrieved from EMBL were aligned and a phylogenetic tree was constructed from the global alignment by using the neighbour-joining method using the BioNumerics software package, version 4.50 (Applied Maths). Bootstrapping analysis was undertaken to test the statistical reliability of the topology of the neighbour-joining tree using 1000 bootstrap resamplings of the data (see Supplementary Fig. S1 available in IJSEM Online). The tree topology obtained with the neighbour-joining method was evaluated and confirmed by maximum-parsimony analysis using BioNumerics (data not shown). Strains LMG 11400 and NRRL B-4435 were classified in the genus Lactobacillus, with $L$. amylophilus LMG $6900^{\mathrm{T}}$ as their nearest neighbour, having $97 \cdot 2 \% 16 \mathrm{~S}$ rRNA gene sequence similarity, a value that is generally accepted as borderline for species delineation (Stackebrandt \& Goebel, 1994). Other Lactobacillus species showed less than $92 \% 16 \mathrm{~S}$ rRNA gene sequence similarity.

Protein fingerprinting is considered as a valuable method for species identification of most lactic acid bacteria (Vandamme et al., 1996). Strains LMG 11400 and NRRL B-4435 and strains LMG $6900^{\mathrm{T}}$, NRRL B-4438, NRRL B4439 and NRRL B-4440 of L. amylophilus were investigated using PAGE of whole-cell proteins. Whole-cell protein extracts were prepared and SDS-PAGE was performed as described by Pot et al. (1994). Densitometric analysis, normalization and interpolation of protein profiles, and numerical analysis were performed by using the GelCompar software package, versions 3.1 and 4.0, respectively (Applied Maths). Strains LMG $6900^{\mathrm{T}}$, NRRL B-4438, NRRL B-4439 and NRRL B-4440 showed identical protein patterns. Strains LMG 11400 and NRRL B-4435 could be differentiated from each other by the varying position of a dominant protein band in the molecular mass range of 40 to $50 \mathrm{kDa}$. After omitting this variable region from the cluster analysis, strains LMG 11400 and NRRL B-4435 constituted a highly homogeneous cluster showing a more distant relationship to the type strain of L. amylophilus, LMG $6900^{\mathrm{T}}$, and the other three reference strains of the species (Fig. 2). Strain-specific variable dense bands may indicate the presence of S-layer proteins, which are highly expressed and form a paracrystalline coat outside the bacterial cell wall (Sleytr \& Sara, 1997). As these proteins are surface-exposed and play a role in survival and adaptation to the environment, differences between members of the same species can be seen in protein SDS-PAGE (Boot et al., 1996).

The DNA G $+\mathrm{C}$ content was determined for strain LMG 11400. Cells were cultivated in MRS broth at $37^{\circ} \mathrm{C}$ for $24 \mathrm{~h}$. DNA was extracted from $0 \cdot 5-0 \cdot 75 \mathrm{~g}$ (wet weight) by using the protocol described by Marmur (1961) with the following modifications: (i) cells were suspended overnight in Tris/ $\mathrm{HCl}$ buffer containing lysozyme $\left(8 \mathrm{mg} \mathrm{ml}^{-1}\right)$ before addition of SDS and (ii) lysed cells were treated with proteinase $\mathrm{K}$ (360 $\mathrm{mg} \mathrm{l}^{-1}$; Merck) at $37^{\circ} \mathrm{C}$ for $2 \mathrm{~h}$. For determination of the DNA G $+\mathrm{C}$ content, DNA was degraded enzymically into nucleosides as described by Mesbah et al. (1989). The nucleoside mixture was then separated by HPLC using a Waters SymmetryShield C8 column maintained at a temperature of $45^{\circ} \mathrm{C}$. The solvent was $0.3 \mathrm{M} \mathrm{NH}_{4} \mathrm{H}_{2} \mathrm{PO}_{4}(\mathrm{pH} 4 \cdot 4)$ with $1.5 \%$ acetonitrile. Non-methylated $\lambda$-phage DNA (Sigma) was used as the calibration reference. The DNA G+C content of strain LMG 11400 was $43.5 \mathrm{~mol} \%$. In comparison, Nakamura \& Crowell (1979) reported comparable DNA G + C contents for strains LMG 11400 and NRRL B-4435 (44 mol\%) and the other four reference strains of L. amylophilus (46 mol\%). 

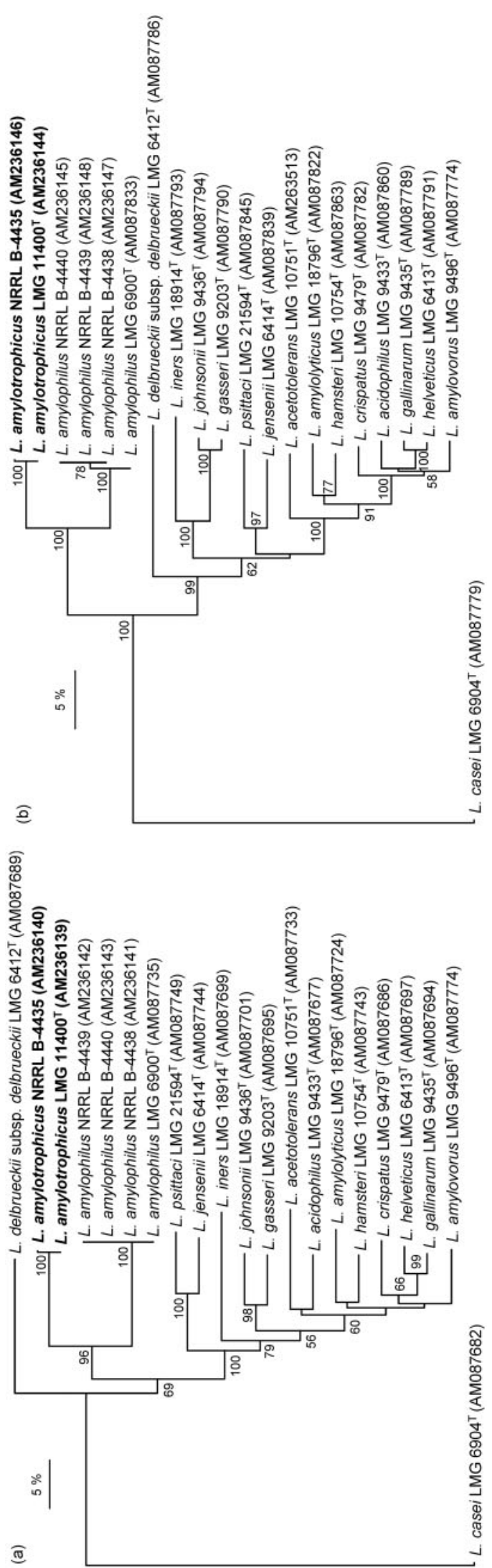

Fig. 1. Neighbour-joining trees showing relationships between strains LMG 11400 and NRRL B-4435 (L. amylotrophicus sp. nov.), L. amylophilus strains and other Lactobacillus reference species based on comparisons of pheS (a) and rpoA (b) gene sequences. Lactobacillus casei LMG $6904^{\top}$ was used as an outgroup. Bootstrap percentages $(\geqslant 50 \%)$ after 1000 simulations are shown. Bars, $5 \%$ sequence divergence. Accession numbers are given in parentheses.

The heterogeneity observed in this study among strains of $L$. amylophilus is clearly in contrast to the reported data of Nakamura (1982) and indicates that it is necessary to reinvestigate the DNA-DNA reassociation among these strains. DNA-DNA hybridizations were performed between strains LMG 11400 and NRRL B-4435 and strains LMG $6900^{\mathrm{T}}$ and NRRL B-4439 of L. amylophilus. Genomic DNA was prepared as described by Naser et al. (2006). The microplate method was used as described by Ezaki et al. (1989) and Goris et al. (1998), using an HTS7000 BioAssay Reader (Perkin Elmer) for the fluorescence measurements. Biotinylated DNA was hybridized with unlabelled singlestranded DNA, which was bound non-covalently to microplate wells. Hybridizations were performed at $36^{\circ} \mathrm{C}$ in hybridization mixture $(2 \times$ SSC, $5 \times$ Denhardt's solution, $2 \cdot 5 \%$ dextran sulfate, $50 \%$ formamide, $100 \mu \mathrm{g}$ denatured salmon sperm DNA ml ${ }^{-1}, 1250$ ng biotinylated probe DNA $\mathrm{ml}^{-1}$ ). Reciprocal reactions were performed. The DNA-DNA binding values reported are the mean values of a minimum of four hybridization experiments, including the reciprocal reactions. High DNA-DNA hybridization levels (94\%) were found between strains LMG 11400 and NRRL B-4435, indicating clearly that the two strains belong to the same species, whereas low DNADNA reassociation values, in the range 36-40\%, were observed between the latter two strains and the type strain of L. amylophilus and strain NRRL B-4439. These results contradict the DNA-DNA reassociation values reported by Nakamura (1982), who showed high DNA-DNA reassociation (90-98\%) among strains of L. amylophilus.

Growth characteristics and colony morphology were investigated on MRS agar ( $\mathrm{pH} 5 \cdot 4$ ) after $24 \mathrm{~h}$ of incubation at $28{ }^{\circ} \mathrm{C}$ under aerobic conditions. Carbohydrate fermentation tests were carried out using API50 CHL galleries following the instructions of the manufacturer (bioMérieux). The results are given below in the species description.

Due to the contradictory results between the present study and those performed by Nakamura \& Crowell (1979) and Nakamura (1982), we reinvestigated the fermentation patterns of three sugars, amygdalin, salicin and cellobiose, using a conventional method, as in the original description by Nakamura \& Crowell (1979). This is because the carbohydrate fermentation tests in the API50 CHL gallery are reliable for $48 \mathrm{~h}$ but not after 3-7 days. The same set of strains analysed by SDS-PAGE was screened for growth on amygdalin, salicin and cellobiose. Cultures were first 


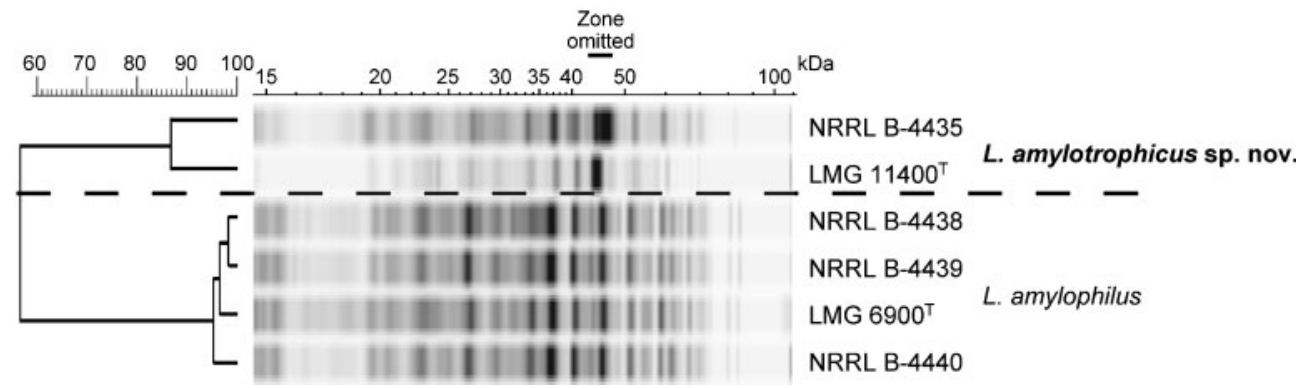

Fig. 2. Protein profiles and corresponding dendrogram derived from UPGMA linkage of correlation coefficients ( $r$, expressed as a percentage for convenience) of strains LMG 11400 and NRRL B-4435 (L. amylotrophicus sp. nov.) and L. amylophilus strains.

inoculated in Difco MRS broth for $24 \mathrm{~h}$ and they were then transferred twice more to MRS broth, after which $1 \mathrm{ml}$ culture was centrifuged at 7000 r.p.m. for $15 \mathrm{~min}$ and resuspended in $1 \mathrm{ml}$ sterile physiological solution $(0.85 \%$, $\mathrm{w} / \mathrm{v})$. The resulting suspension in physiological solution was used as the inoculum for the test media. All strains were incubated in $10 \mathrm{ml}$ test tubes at $30^{\circ} \mathrm{C}$. The inoculum size was $1 \%(\mathrm{v} / \mathrm{v})$ throughout the experiment. All experiments were performed twice. Growth on all three substrates, amygdalin, salicin and cellobiose, was observed for LMG 11400, which confirms data reported previously (Nakamura \& Crowell, 1979). However, strain NRRL B-4435, which was expected to grow on amygdalin, salicin and cellobiose, showed growth on cellobiose and salicin after 7 days of incubation but it did not show any growth on amygdalin. Consequently, the phenotypic properties that can be used to differentiate the novel taxon from $L$. amylophilus are the production of acid from D-cellobiose and salicin. The production of acid from amygdalin is strain-dependent.

The same set of strains analysed by SDS-PAGE was tested for starch fermentation and the production of D- and L-lactic acid. Starch was used by all strains, as expected. Inoculating the strains on solid MRS medium with starch as a carbon source showed that all strains produced colonies with clearing zones around the colonies caused by degradation of the starch. This result confirmed that both L. amylophilus and the novel taxon are starch-utilizing species. The amounts of D- and L-lactic acid were determined with a Boehringer Mannheim D-lactic acid/L-lactic acid UVmethod enzymic kit. Determinations of D- and L-lactic acid were performed on cultures grown on glucose as a carbon source after $24 \mathrm{~h}$ of incubation. Determination of the percentages of D- and L-lactic acid showed that all strains produced exclusively $\mathrm{L}(+)$-lactic acid, which is in agreement with previous findings (Nakamura \& Crowell, 1979).

The overall results of the present study allowed the assignment of two strains, LMG 11400 and NRRL B-4435, to a novel species, for which we propose the name Lactobacillus amylotrophicus sp. nov.

\section{Description of Lactobacillus amylotrophicus sp. nov.}

Lactobacillus amylotrophicus (a.my.lo.tro'phi.cus. Gr. n. amulon starch; N.L. adj. trophicus from Gr. adj. trophikos nursing, tending; N.L. masc. adj. amylotrophicus growing on starch, pertaining to the ability to ferment starch).

Cells are rod-shaped, occurring singly or in pairs and chains, $1 \cdot 2-2 \cdot 0 \mu \mathrm{m}$ long and $0.9 \mu \mathrm{m}$ wide, Gram-positive, catalasenegative, oxidase-negative, non-spore-forming and nonmotile. After $24 \mathrm{~h}$, colonies are white, smooth, circular and approximately $1 \mathrm{~mm}$ in diameter. Growth occurs at $15^{\circ} \mathrm{C}$ but not at $45^{\circ} \mathrm{C}$. Facultatively anaerobic and produces $\mathrm{L}(+)$ lactic acid homofermentatively from glucose and starch. No gas produced from glucose. Acid is produced in the API 50 $\mathrm{CH}$ kits in tests with D-galactose, D-glucose, D-fructose, Dmannose, $N$-acetylglucosamine, aesculin, D-cellobiose, Dmaltose, starch, glycogen and gentiobiose. No acid is produced from glycerol, erythritol, D- or L-arabinose, Dribose, $\mathrm{D}$ - or L- xylose, D-adonitol, methyl $\beta$-D-xylopyranoside, L-sorbose, L-rhamnose, dulcitol, inositol, D-mannitol, D-sorbitol, methyl $\alpha$-D-mannopyranoside, methyl $\alpha$-Dglucopyranoside, arbutin, D-lactose, D-melibiose, sucrose, D-trehalose, inulin, D-melezitose, D-raffinose, xylitol, Dturanose, D-lyxose, D-tagatose, D- or L-fucose, D- or Larabitol, gluconate or 2- or 5-ketogluconate. Production of acid from amygdalin is strain-dependent. The DNA G+C content of the type strain is $43 \cdot 5 \mathrm{~mol} \%$.

The type strain is LMG $11400^{\mathrm{T}}\left(=\mathrm{NRRL} \mathrm{B}-4436^{\mathrm{T}}=\mathrm{DSM}\right.$ $20534^{\mathrm{T}}$ ), which was isolated from swine waste-corn fermentation.

\section{Acknowledgements}

The authors acknowledge grants from the Ministry of Education and Higher Education (PhD scholarship of S. M. N.), the Prime Minister's Services (Federal Office for Scientific, Technical and Cultural Affairs Belgium), the Fund for Scientific Research Flanders (FWOVlaanderen) and the Institute for the Encouragement of Scientific Research in Industry (IWT-Vlaanderen). 


\section{References}

Boot, H. J., Kolen, C. P. A. M., Pot, B., Kersters, K. \& Pouwels, P. H. (1996). The presence of two S-layer-protein-encoding genes is conserved among species related to Lactobacillus acidophilus. Microbiology 142, 2375-2384.

Ezaki, T., Hashimoto, Y. \& Yabuuchi, E. (1989). Fluorometric deoxyribonucleic acid-deoxyribonucleic acid hybridization in microdilution wells as an alternative to membrane filter hybridization in which radioisotopes are used to determine genetic relatedness among bacterial strains. Int J Syst Bacteriol 39, 224-229.

Gevers, D., Huys, G. \& Swings, J. (2001). Applicability of rep-PCR fingerprinting for identification of Lactobacillus species. FEMS Microbiol Lett 205, 31-36.

Goris, J., Suzuki, K., De Vos, P., Nakase, T., Kersters, K. (1998). Evaluation of a microplate DNA-DNA hybridization method compared with the initial renaturation method. Can J Microbiol 44, 1148-1153.

Marmur, J. (1961). A procedure for the isolation of deoxyribonucleic acid from microorganisms. J Mol Biol 3, 208-218.

Mesbah, M., Premachandran, U. \& Whitman, W. B. (1989). Precise measurement of the $\mathrm{G}+\mathrm{C}$ content of deoxyribonucleic acid by highperformance liquid chromatography. Int J Syst Bacteriol 39, 159-167.

Nakamura, L. K. (1982). Deoxyribonucleic acid homologies of Lactobacillus amylophilus and other homofermentative species. Int J Syst Bacteriol 32, 43-47.

Nakamura, L. K. \& Crowell, C. D. (1979). Lactobacillus amylophilus, a new starch-hydrolyzing species from swine waste-corn fermentation. Dev Ind Microbiol 20, 532-540.

Naser, S. M., Thompson, F. L., Hoste, B., Gevers, D., Dawyndt, P., Vancanneyt, M. \& Swings, J. (2005a). Application of multilocus sequence analysis (MLSA) for rapid identification of Enterococcus species based on rpoA and pheS genes. Microbiology 151, 2141-2150.

Naser, S. M., Vancanneyt, M., De Graef, E. \& 8 other authors (2005b). Enterococcus canintestini sp. nov., from faecal samples of healthy dogs. Int J Syst Evol Microbiol 55, 2177-2182.

Naser, S. M., Hagen, K. E., Vancanneyt, M., Cleenwerck, I., Swings, J. \& Tompkins, T. A. (2006). Lactobacillus suntoryeus Cachat and Priest
2005 is a later synonym of Lactobacillus helveticus (Orla-Jensen 1919) Bergey et al. 1925 (Approved Lists 1980). Int J Syst Evol Microbiol 56, 355-360

Niemann, S., Puehler, A., Tichy, H. V., Simon, R. \& Selbitschka, W. (1997). Evaluation of the resolving power of three different DNA fingerprinting methods to discriminate among isolates of a natural Rhizobium meliloti population. J Appl Microbiol 82, 477-484.

Pot, B., Vandamme, P. \& Kersters, K. (1994). Analysis of electrophoretic whole-organism protein fingerprints. In Chemical Methods in Prokaryotic Systematics, pp. 493-521. Edited by M. Goodfellow \& A. G. O’Donnell. Chichester: Wiley.

Sleytr, U. B. \& Sara, M. (1997). Bacterial and archaeal S-layer proteins: structure-function relationships and their biotechnological applications. Trends Biotechnol 15, 20-26.

Stackebrandt, E. \& Goebel, B. M. (1994). Taxonomic note: a place for DNA-DNA reassociation and 16S rRNA sequence analysis in the present species definition in bacteriology. Int J Syst Bacteriol 44, 846-849.

Stackebrandt, E., Frederiksen, W., Garrity, G. M. \& 10 other authors (2002). Report of the ad hoc committee for the re-evaluation of the species definition in bacteriology. Int J Syst Evol Microbiol 52, 1043-1047.

Švec, P., Vancanneyt, M., Koort, J., Naser, S. M., Hoste, B., Vihavainen, E., Vandamme, P., Swings, J. \& Björkroth, J. (2005). Enterococcus devriesei sp. nov., associated with animal sources. Int J Syst Evol Microbiol 55, 2479-2484.

Vancanneyt, M., Mengaud, J., Cleenwerck, I. \& 7 other authors (2004). Reclassification of Lactobacillus kefirgranum Takizawa et al. 1994 as Lactobacillus kefiranofaciens subsp. kefirgranum subsp. nov., and emended description of L. kefiranofaciens Fujisawa et al. 1988. Int J Syst Evol Microbiol 54, 551-556.

Vandamme, P., Pot, B., Gillis, M., de Vos, P., Kersters, K. \& Swings, J. (1996). Polyphasic taxonomy, a consensus approach to bacterial systematics. Microbiol Rev 60, 407-438.

Zeigler, D. R. (2003). Gene sequences useful for predicting relatedness of whole genomes in bacteria. Int J Syst Evol Microbiol 53, 1893-1900. 